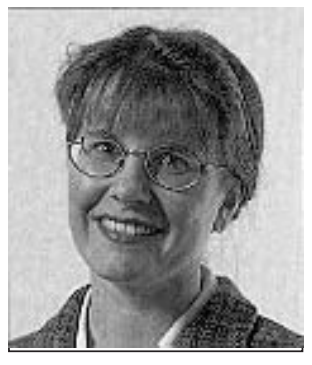

Leena Tuomi

\title{
Miten tukea oppimista organisaatiossa?
}

\section{Kokemuksia eurooppalaisesta PD-ohjelmasta EuroPro}

\begin{abstract}
EuroPro - European Professional Development Programme - on EU:n COMETT II -ohjelman puitteissa kehitetty eurooppalainen täydennyskoulutusohjelma, jonka rakenne ja laajuus vastaavat suomalaista PD-ohjelmaa. EuroPro diplomin myöntää EuroPro Board, jossa ovat edustettuina mm. SEFI ja FEANI, jotka ovat eurooppalaisia insinöörijärjestöjä. Ohjelmaa koordinoi Teknillisen korkeakoulun Koulutuskeskus Dipoli.
\end{abstract}

EuroPro tarjoaa organisaatioille systemaattisen ja motivoivan tavan kehittää asiantuntijoita ja projektipäälliköitä organisaation ydinosaamisalueille. Yksilön kannalta EuroPro-opiskelu on tavoitteellista, juuri oikeaan tarpeeseen kohdistuvaa ja johtaa kansainvälisesti tunnustettuun diplomiin. EuroPro-opintojen laajuus on 40 opintoviikkoa, joka koostuu yksilöllisesti koottavista moduuleista (korkeakoulujen ja yliopistojen kurssit, yksityisten koulutuksen järjestäjien kurssit, yrityksen sisäinen koulutus, etä- ja itseopiskelu sekä projektityöt).

EuroPro on alkanut öljy- ja kemianalan yrityksissä ja parhaillaan se on laajenemassa mm. ympäristö- ja telekommunikaatioalalle. Suomalaisista yrityksistä Neste ja Kemira ovat olleet aktiivisesti luomassa ja kehittämässä ohjelmaa. EuroPro-ohjelmassa on tällä hetkellä 70 opiskelijaa, joista noin puolet on asiantuntijoita (kuten tutkijoita tai tuotekehitysinsinöörejä) ja puolet projektipäälliköitä tai osastopäälliköitä. Opiskelijoiden tyypillinen ikä on 35-45 vuotta.

EuroPro -opiskelu on hyvin joustavaa ja räätälöityä, mutta edellyttää opiskelijalta paljon itseohjautuvuutta ja aloitekykyä. Oppijan tueksi EuroPro-opinnoissa on luotu oppijan tukiverkko, josta on saatu hyviä käytännön kokemuksia jo viiden vuoden ajalta.

Tukiverkko auttaa opiskelijaa suuntaamaan opintojaan organisaation tarpeiden mukaisesti ja kannustaa häntä saamaan opinnot päätökseen. Elinikäinen oppiminen ja jatkuva opiskelu, kuten EuroPron suorittaminen, ovat vaativia haasteita työssä olevalle aikuiselle. Työn ohessa tapahtuva tavoitteellinen opiskelu jää usein kesken, jollei opiskelija saa riittävää kannustusta ja tukea ainakin omassa organisaatiossaan. Tuen saaminen tarvittaessa voidaan varmistaa luomalla jo opintojen alussa oppijalle tukiverkko, jonka puoleen oppija voi tarvittaessa kääntyä.

\section{Oppijan tukiverkko}

Oppijan tukiverkko (kuvio 1) koostuu opiskelijan esimiehestä, mentorista (samasta organisaatiosta), tutorista (professori korkeakoulussa) ja opintoneuvojasta (korkeakoulussa). Tu- 


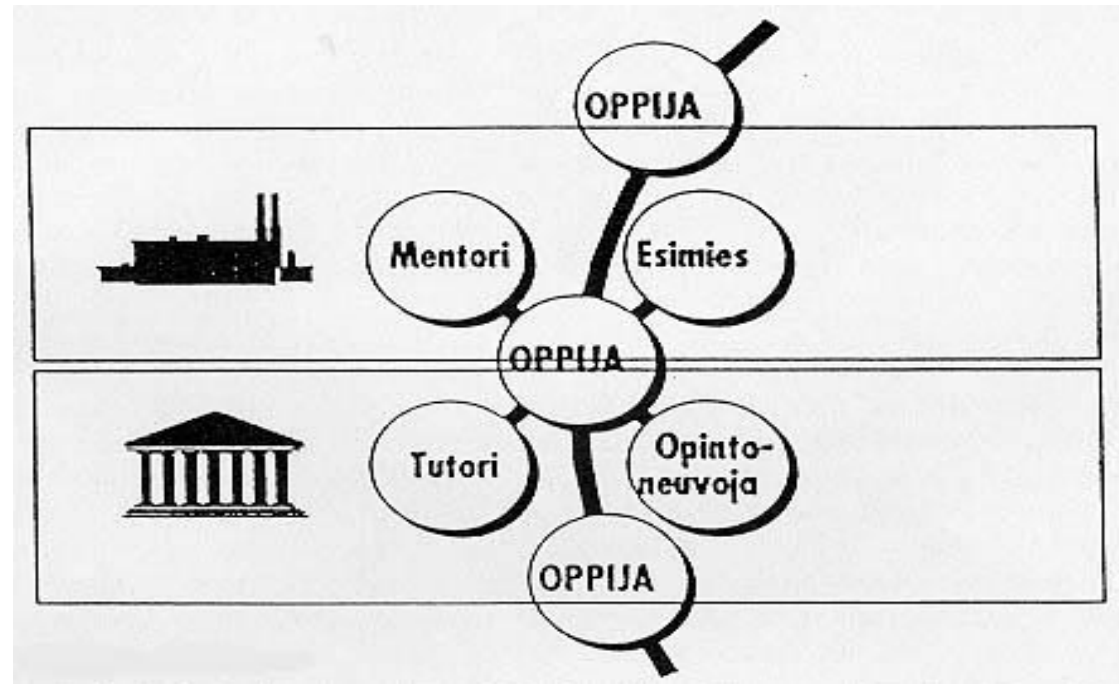

Kuvio 1: Oppijan tukiverkon rakenne

kiverkoston toimijat toimivat rooleissaan vapaaehtoisesti ja oman työnsä ohessa. Jotta verkosto toimii tarkoituksenmukaisesti, siinä mukana olevat henkilöt tarvitsevat koulutusta rooliinsa.

\section{simies}

Esimiehen rooli oppijan tukijana on erittäin tärkeä, sillä hän varmistaa opiskelun rahoituksen ja antaa opinnoille organisaation haluamaa suuntaa. Esimiehen tehtävänä on käydä oppijan kanssa kehityskeskustelu, jonka tuloksena on kehityssuunnitelma seuraavalle vuodelle tai muulle ajanjaksolle. Kehityssuunnitelman tulisi olla osa pidemmän aikavälin opintosuunnitelmaa, jonka tavoitteena on esimerkiksi tutkinto tai jokin muu kokonaisuus. Kehityskeskustelussa tarkennetaan myös opintosuunnitelmaa ja tehdään siihen tarvittavat muutokset. Kehityssuunnitelman tulee vastata organisaation osaamistarpeisiin, jotka on johdettu organisaation strategioista ja tavoitteista. Jos tämä kytkentä on löyhä, tavoitteelliselle opiskelulle on vaikea hakea organisaation tukea. Jos taas yrityksessä nähdään, että kehityssuunnitelman toteuttaminen lisää osaamista strategisesti merkittävillä alueilla, niin tuen ja kannustuksen saaminen kehittymiselle on todennäköistä.

Esimies kantaa vastuun oppijasta orga- nisaatiolle. Jos oppijan työsuoritus ei ole odotusten mukainen, esimies raportoi siitä omalle esimiehelleen. Esimies onkin usein kiinnostunut lyhyen aikavälin tulosten parantamisesta ja kehittämisestä, joka auttaa tekemään työn paremmin tänä päivänä tai lähitulevaisuudessa. Vastuun kantaminen oppijasta organisaatiolle tarkoittaa myös taloudellisen vastuun kantamista. Kehittyminen vaatii yleensä aina jonkinlaisia taloudellisia ja ajallisia panostuksia. Esimies toimiikin myös sponsorin roolissa.

Esimiehen rooliin kuuluu olla valmentajana eli hän asettaa yhdessä oppijan kanssa tavoitteet oppimiselle, antaa tukea, kannustaa ja antaa palautetta edistymisestä.

Esimiehen rooli ja tehtävät oppijan tukiverkossa ovat vaativia, mutta ne eivät eroa niistä vaatimuksista, joita hyvälle esimiehelle nykyään asetetaan. Kuitenkin on muistettava, että esimiehet itsekin tarvitsevat valmennusta selviytyäkseen jatkuvasti kasvavista odotuksista.

\section{$M^{\text {entori }}$}

Oppijan tukiverkossa mentori on vanhempi asiantuntija mielellään samassa organisaatiossa kuin oppijakin. Hän on oppijan syventymiskohteen asiantuntija, mutta mentoria voidaan kutsua myös kummisedäksi tai -tädiksi. 
Mentori ei ole oppijasta vastuussa organisaatiolle eli hänen ei pitäisi olla oppijan esimiehen esimies tai hänen esimiehensä. Mentorin tulisi olla sama henkilö koko tavoitteellisen opiskelun ajan, koska esimiehet usein vaihtuvat organisaatiomuutosten myötä.

Mentorin kanssa keskusteltaessa oppijan omat toiveet ja tavoitteet ovat etusijalla. Keskusteluissa käsitellään oppijan omia urasuunnitelmia pitkälläkin aikavälillä ja lyhyen aikavälin suunnitelmia siitä, miten pitkän aikavälin tavoitteet saadaan toteutettua. Mentorin pitäisi mielellään olla kokeneempi alallaan kuin oppijan ja hänen tulisi tuntea yrityksen historia ja toimintatavat hyvin. Mentorilla pitää olla visioita siitä, mihin ala on menossa ja millaisia muutoksia on tulossa, jotta hän osaa antaa neuvoja oppijan opintojen suuntaamisesta ja opintosuunnitelman sisällöstä.

Mentorin avulla oppija voi päästä hyödyntämään mentorin kontaktiverkostoa. Mentori voi esitellä oppijan tietyille henkilöille esimerkiksi kehitysprojektiin tarvittavien tietojen hankkimiseksi. Mentorille kuuluu lisäksi samoja tehtäviä kuin esimiehelle eli opintoraporttien lukeminen ja kommentointi, kannustaminen ja tukeminen.

Hyvän mentorin löytäminen omasta organisaatiosta voi olla ongelmallista, varsinkin pienissä organisaatioissa. Jos sopivaa mentoria ei löydy omasta yrityksestä, voi sellainen löytyä alan järjestöstä tai jostain muusta yrityksestä. Hyvä mentori on alansa tunnustettu asiantuntija, kiinnostunut ihmisistä, omaa laajan kontaktiverkoston ja hyvät vuorovaikutustaidot ja on sopiva roolimalli oppijalle.

\section{Tutori}

Tutori on oppijan syventymiskohteen akateeminen asiantuntija, useimmiten professori yliopistossa tai korkeakoulussa. Oppijan tukiverkossa tutori tuo organisaation ulkopuolisen näkemyksen oppijan suunnitelmaan ja projektitöihin. Näin varmistetaan, että yritys saa uusia näkemyksiä ja ideoita, puolueettoman arvioinnin esimerkiksi projektitöissä ja mahdollisuuden hyödyntää kehitysprojekteissa uusinta tutkimustietoa alalta.
Tutori on se taho, joka viime kädessä päättää opintojen laajuuden arvioinnin eli projektitöiden opintoviikotuksen. Lähes kaikissa tutkintoon tähtäävissä opinnoissa on laajempi projektityö, joka yhdistetään oman työhön. Jos työn laajuutta eli opintoviikkomäärää ei ole etukäteen määrätty, tarvitaan alan asiantuntija eli tutori arvioimaan laajuus. Tutori arvioi myös työn laatua, jotta vaatimustaso pidetään riittävän korkealla.

Tutori voi myös vetää oman alansa opintoryhmää, jonka tavoitteena on tukea ja edistää ryhmän jäsenten oppimista. Opintoryhmässä jäsenet kuulevat alan kuulumisia niin tutoreilta kuin muilta opiskelijoilta ja saavat apua opintoihin liittyvissä ongelmissa. Opintoryhmän tapaamiset kahdesta kolmeen kertaa vuodessa antavat konkreettisia välitavoitteita opiskelijalle.

Opintoneuvoja auttaa opiskelijaa löytämään oman alansa tutorin. Tutoriksi etsitään henkilö, joka on alansa arvostettu asiantuntija ja on kiinnostunut ohjaamaan työnsä ohessa opiskelevia.

\section{Pintoneuvoja}

Opintoneuvoja työskentelee korkeakoulussa tai yliopistossa. Hänen tehtävänään on auttaa opiskelijaa tutkinnon ja opintojen suorittamiseen liittyvissä asioissa sekä antaa tukea ja kannustaa oppijaa etenemään opinnoissa.

Opintoneuvojan tulee hallita eri tutkintojen ja diplomien vaatimukset, jotta hän tietää, millaisia opintoja kyseiseen tutkintoon hyväksytään ja miten ne hyväksyttävästi suoritetaan. Opintoneuvoja ohjaa oppijaa löytämään oppijalle sopivaa koulutusta, kuten täydennyskoulutuskursseja tai yliopiston peruskursseja. Tätä varten opintoneuvojalla täytyy olla hyvät tiedonlähteet ja koulutusalan tarjonnan tuntemusta. Opintoneuvojan tulee tuntea suomalainen koulutusjärjestelmä riittävän hyvin, jotta hän tietää, mitä eri koulutus- ja opetusväyliä on kyseiselle oppijalle tarjolla ja miten niihin pääsee. Muiden maiden koulutusjärjestelmien tuntemus tulee tarpeelliseksi silloin, kun oppija on suorittanut ulkomailla opintoja ja haluaa ne 
Tarpeet/Vaatimukset

Organisaatio

Korkeakoulu
ESIMIES

-organisaation osaamistarpeet

OPINTONEUVOJA

-tutkintovaatimukset

\section{Sisältö}

MENTORI

- tiedon soveltaminen organisaatiossa

TUTORI

- opintojen tieteellisyys osaksi jotain tutkintoa. Opinnot täytyy yhteismitallistaa eli Suomessa opintoviikottaa.

Opintoneuvoja auttaa oppijaa tekemään henkilökohtaisen opinto- tai kehityssuunnitelman. Tässä roolissa hänen tehtävänään on esittää oikeita kysymyksiä, joihin oppijan pitää itse löytää vastaukset. Opintoneuvoja auttaa löytämään sopivia opintomoduuleja, kunhan ensin tiedetään, mitä uutta osaamista henkilö todella tarvitsee.

Opintoneuvoja huolehtii lisäksi opintojen hallinnollisista asioista, kuten opiskelijaksi hyväksymisistä, opintorekisterin ylläpidosta ja diplomista.
Tässä esiteltyyn oppijan tukiverkkomalliin on otettu mukaan pitkäkestoisten täydennyskoulutusohjelmien suorittamisen kannalta tärkeimmät toimijat. Oppijalle muita tärkeitä tukijoita, joita tässä ei ole tarkasteltu, ovat muut opiskelijat, työkaverit ja kolleegat, perhe, sukulaiset ja ystävät. Työn ohessa ja työssä opiskelu vaikuttaa opiskelijan koko elämään.

Oppijan tukiverkon eri toimijoiden rooleja voidaan tarkastella myös sitä kautta mitä oppija kultakin toimijalta saa. Kunkin toimijan antama lisäarvo oppijalle voidaan jakaa oppimisen sisältöön tai organisaation tarpeisiin ja tutkintovaatimuksiin. Tällöin saadaan taulukossa 1 esitetty nelikenttä kunkin roolin painotuksesta.

EuroPron projektipäällikkö LeenaTuomi, EuroPro-tutkinnon suorittanutja tutorointia köyttänyt R\&DAssociate Heidi Österholm Nesteeltä sekä tutor,Teknillisen korkeakoulun kemian professori Jukka Seppänen. Heidi kartutti asiantuntemustaan Nesteen kannalta tärkeällä kemian erityisalueella, missä tietämys haettiin ulkomailta. "Kokemuksieni mukaan tavoitteenmäärittelyn ohella osapuolten aito sitoutuminen täydennyskoulutushankkeeseen on onnistumisen edellyłys", sanoo Jukka Seppänen. Siksi esimerkiksi esimiesvaihdos tai organisaatiomuutossaattavattuoda ongelmia työnantajan sitoutumisessa.

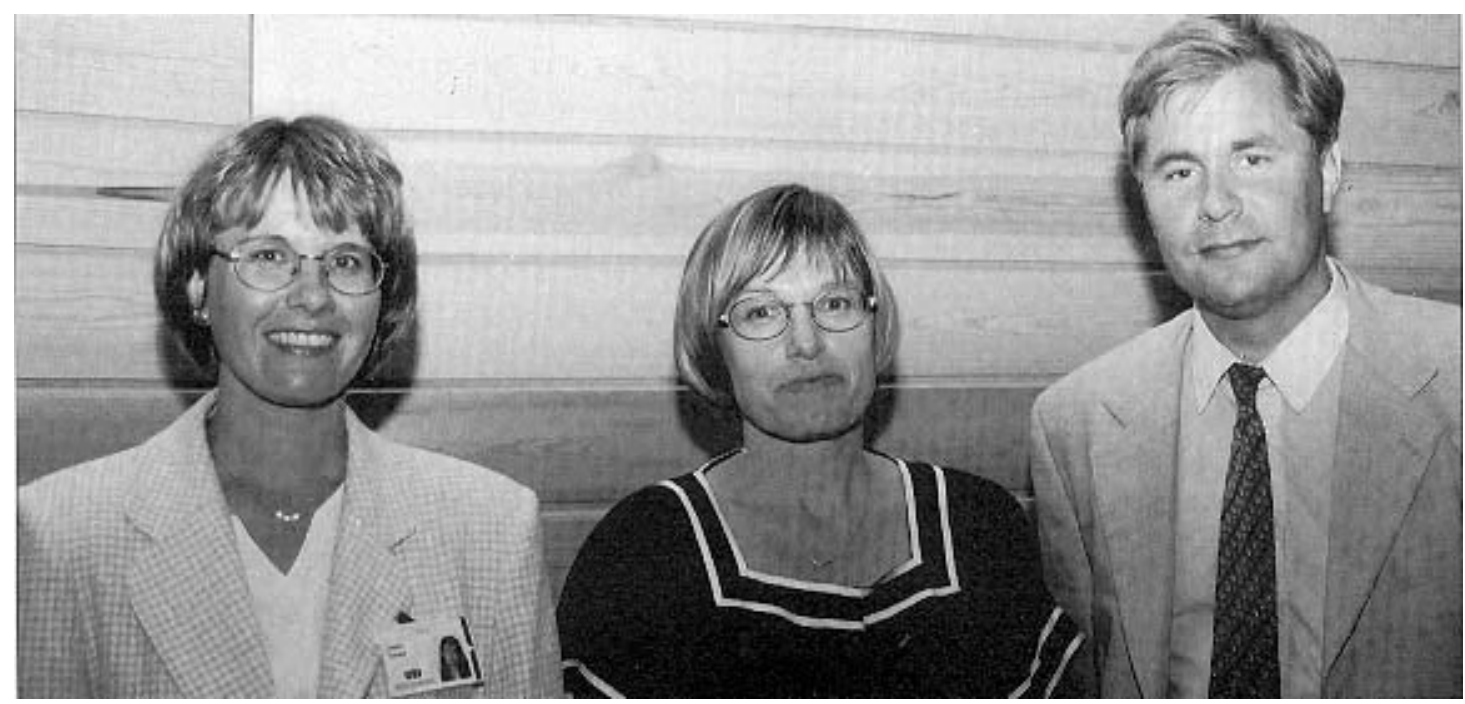

